\title{
Michał Duda
}

https://orcid.org/0000-0003-4227-1418

Uniwersytet Łódzki

Wydział Nauk Geograficznych

Instytut Geografii Miast, Turyzmu i Geoinformacji

michal.duda@geo.uni.lodz.pl

\section{WYKORZYSTANIE METOD SOCJOLOGII WIZUALNEJ W GEOGRAFICZNYCH BADANIACH PRZESTRZENI MIEJSKIEJ - ANALIZA FOTOGRAFII WYKONANYCH PRZEZ TURYSTÓW W ŁODZI}

\begin{abstract}
Abstrakt: Celem artykułu jest zaprezentowanie możliwości wykorzystania w badaniach geograficznych jednej z metod socjologii wizualnej - analizy fotografii. W niniejszej pracy analizie poddane zostały wykonane przez turystów zdjęcia, które według nich najlepiej oddawały pobyt w Łodzi. Oprócz typowego dla badań socjologicznych odczytania treści fotografii, znaczeń oraz informacji o autorze, badanie zostało rozbudowane o aspekt przestrzenny, uwzgledniający miejsca wykonania fotografii $\mathrm{i}$ ich powiązania m.in. z lokalizacją najpopularniejszych atrakcji turystycznych miasta. W wyniku tej pracy powstała mapa, wyznaczająca „przestrzeń turystyczną Łodzi” według kryterium wizualnego, która pokazuje jedną z możliwości wykorzystania analiz fotografii $\mathrm{w}$ badaniach geograficznych związanych z turystyką. W artykule zaprezentowano, jakie wyniki można otrzymać na podstawie analizy zdjęć, wykorzystując cztery różne podejścia i metody interpretacji (strukturalistyczną, hermeneutyczną, semiologiczną oraz geograficzną).
\end{abstract}

Słowa kluczowe: analiza fotografii, socjologia wizualna, turystyka, postrzeganie miasta, przestrzeń turystyczna.

\section{APPLICATION OF VISUAL SOCIOLOGY METHODS IN GEOGRAPHICAL STUDIES OF URBAN SPACE THROUGH AN ANALYSIS OF PHOTOS TAKEN BY TOURISTS: A CASE STUDY OF ŁÓDŹ}

Abstract: The aim of this paper is to present the possibility of using visual sociology method - photographic analysis - in geographical research. In this case study, the author analyzed photographs taken by tourists during their stay in Łódź which, according to them, "best reflect their stay in this city". In addition to approaches typical for sociological research, the study was expanded by the spatial aspect including the places where the photographs were taken and their association with the most popular tourist attractions of the city. The outcome of this work is a map delineating the "tourism space of Łódź" (according to the visual criterion) which shows one of the possibilities of using analysis of photographs in geographical research. The paper presents the results that can be obtained from the analysis, using four different approaches and methods of interpretation (structuralist, hermeneutical, semiological and geographical).

Keywords: photography analysis, visual sociology, tourism, city perception, tourism space.

\section{WPROWADZENIE}

Jak pisze Sontag (1978, s. 23): „Fotografie, nawet gdy same nie potrafią nic wyjaśnić, stanowią nieustające zaproszenie do dedukcji, spekulacji i fantazji". Analiza fotografii wykonanych przez turystów, wydaje się cennym źródłem wiedzy - wszak, jak zaznacza Konecki (2005) - fotografie to „protezy pamięci”. Badacz dzięki fotografiom zyskuje znaczący materiał interpretacyjny, który może uzupełnić lub postawić w nowym świetle inne dane, zebrane $w$ ramach tradycyjnych metod badawczych, np. ankiet czy wywiadów. J. Prosser i D. Schwartz twierdza, że „fotografie [...] mogą ukazać charakterystyczne atrybuty ludzi, przedmiotów czy zdarzeń, które często umykają uwadze nawet najbardziej wprawnych rzemieślników słowa pisanego" (Prosser, Schwartz, 1998, s. 116).

Uznano zatem za interesujące powiązanie metody analizy fotografii z odniesieniem do przestrzeni, np. lokalizacji odwiedzanego miejsca. Zagadnienie jest zajmujące również ze względu na to, że współcześnie trwa rozkwit kultury wizualnej (Bogunia-Borowska, Sztompka, 2012). Środkami przekazu są krótkie i treściwe informacje - memy ${ }^{1}$, zdjęcia i krótkie filmiki 
w mediach społecznościowych, wypowiedziami stają się uniwersalne w każdym języku piktogramy i emotikony. Artykuły, relacje czy dyskusje zastępowane są przez galerie i obrazowe wyjaśnienia. W reklamie odchodzi się od treści słownej lub pisanej na rzecz krótkiego hasła i epatowania obrazami. Zdjęcia stają się recenzjami doświadczanych rzeczy, emocji i miejsc. Zwłaszcza w turystyce i geograficznych badaniach społecznych, szeroko rozumiana kultura wizualna zaczyna być istotnym nośnikiem treści interesujących dla badaczy, co w przeglądzie dotychczasowych badań nad rolą zdjęć w projektowaniu wizerunku miejsca wśród turystów pokazali Picazo i Moreno-Gil (2019).

Analiza treści fotografii od dawna wykorzystywana jest $\mathrm{w}$ różnych badaniach, zdarza się, że również w tych dotyczących geografii i turystyki. Przykładem może być np. praca Chlebuś-Grudzień (2018) o zjawisku selfie w muzeum lub opracowanie Puttillego (2020) poruszające złożoną tematykę dziennych ścieżek życia. Analizom poddawane są także zdjęcia używane w materiałach promocyjnych lub mediach (np. Hunter, 2012; Stepchenkova, Zhan, 2013).

Obecnie rozwijają się badania fotografii związanych z przestrzenią geograficzna, wykorzystujące dane GPS zapisane $\mathrm{w}$ danych pliku udostępnianego np. w mediach społecznościowych (np. García-Palomares, Gutierrez, Mínguez, 2015; Tammet, Luberg, Jarv, 2013). Warto wspomnieć również o badaniach przestrzeni geograficznej, w których respondentom pokazuje się przygotowane przez badaczy fotografie - np. dotyczące postrzegania krajobrazu (np. Jakiel, Bernatek, 2015; Mirowska, Krysiak, 2015; Podhorecka, 2016).

W niniejszym artykule analizie poddane zostały zdjęcia wykonane przez turystów podczas pobytu w Łodzi. Praca ta uzupełniała szersze badania wizerunkowe miasta (oparte głównie na wywiadach swobodnych), prowadzone w ramach większego projektu badawczego będącego podstawą rozprawy doktorskiej autora. Ze względu na jakościowe podejście do badań i niewielką liczbę badanych analiza fotografii była raczej testowaniem metody niż pełnoprawnym badaniem. Artykuł ma zatem na celu pokazanie wybranego sposobu badania turystów, dzięki czemu może inspirować kolejnych badaczy do rozbudowy i testowania tej metody w innych warunkach. Tym samym poniekąd wpisuje się w apel Kotusa i Rzeszowskiego (2015) o stosowanie metod mieszanych $w$ badaniach nad turystyką oraz o próby wykorzystywania m.in. metody quasi-eksperymentu behawioralnego.

Uzupełniającym, w stosunku do socjologicznego punktu widzenia, elementem interpretacji jest przestrzenne podejście do analizy fotografii, obejmujące analizę miejsc ich wykonania. Współcześnie jest to główny nurt badań fotografii w turystyce (na podstawie danych zdjęcia i jego lokalizacji GPS) - w artykule pokazano, że można taką analizę przeprowadzić również na podstawie treści zdjęć, bez uwzględniania cyfrowych danych lokalizacyjnych. W przypadku niektórych fotografii było to zadanie trudne i wymagające dobrej znajomości badanej przestrzeni.

\section{PROBLEM BADAWCZY W ŚWIETLE LITERATURY}

Analiza fotografii jest jedną z metod tzw. socjologii wizualnej (rys. 1). Obejmuje ona zdecydowanie węższy zakres wyjaśniania rzeczywistości, niż szerzej rozumiane badania kultury wizualnej, do której zalicza się np.: malarstwo, grafikę, telewizję, rzeźbę, reklamę, gry komputerowe itp. (Sztompka, 2005). To dyscyplina (albo wręcz specjalizacja dyscypliny - socjologii - jak precyzują Emmison, Smith, 2000) stosunkowo

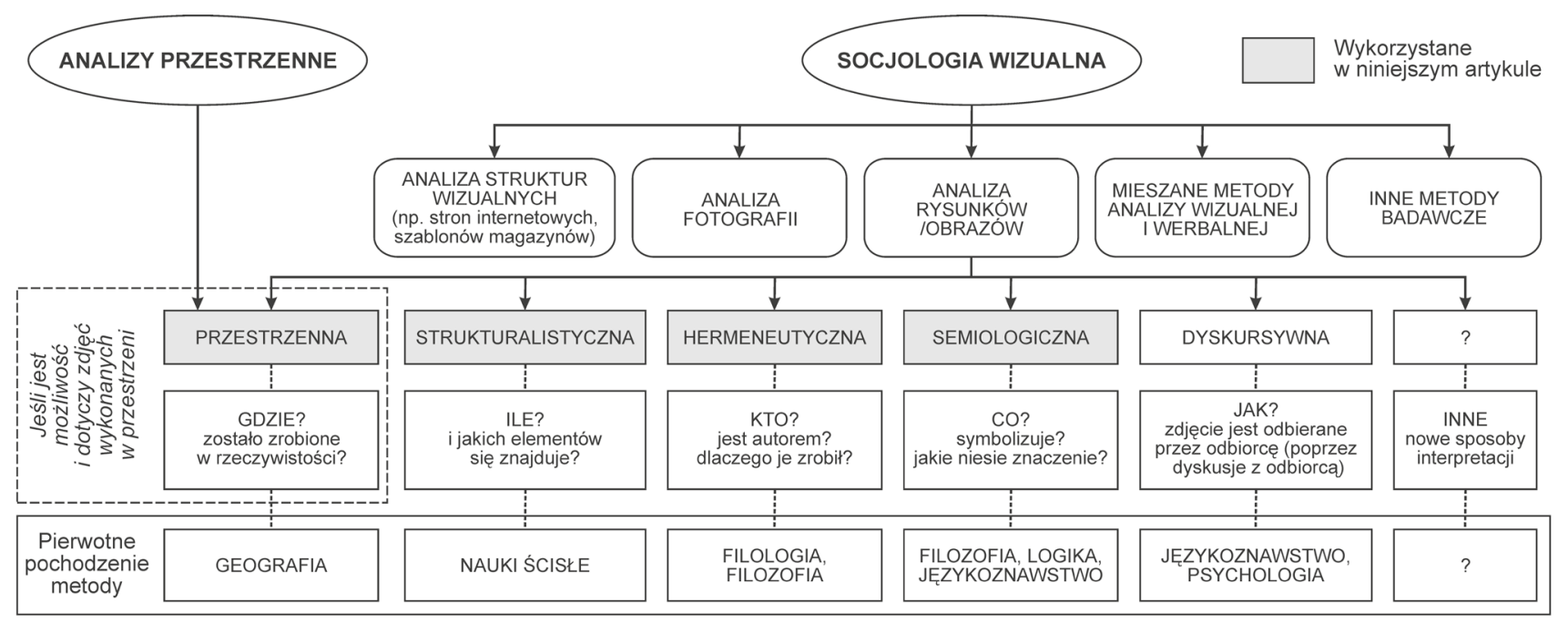

Rysunek 1. Podział metod interpretacyjnych analizy fotografii Źródło: opracowanie własne 
młoda - poważnie zaczęto się nią interesować w latach 90. XX w., a pierwsze kompendium prowadzonych dotychczas badań, zredagował Becker (1981). Warto zaznaczyć, że fotografie $\mathrm{w}$ badaniach socjologicznych wykorzystywane były już dużo wcześniej, np. do zobrazowania życia tubylców czy życia członków gangów w Chicago (Trasher, 1927).

Socjologia wizualna $\mathrm{w}$ zasadzie do dzisiaj w pełni się nie ukonstytuowała, a jej definicja pojawiła się dopiero w 1994 r. w oksfordzkim Stowniku socjologii i nauk społecznych, ciagle postrzegana jest jako nieco ekscentryczny dodatek do „normalnych” badań (Sztompka, 2005). Wynika to zapewne, jak pisze Leonard M. Henny we wprowadzeniu do Theory and Practise of Visual Sociology, „z zamknięcia nauk w kręgu Gutenberga: (gdzie) słowa i liczby są najważniejsze, obrazy wizualne - podejrzane" (Henny, 1986, s. 86). Niemniej jednak, współcześnie, $\mathrm{w}$ dobie nasycenia treściami wizualnymi, nie możemy umniejszać roli badań związanych z „,widzialnym" obrazem świata. Jak pisze Barnard (2001, s. 4): „Jesteśmy coraz bardziej poddawani wpływowi materiałów wizualnych i od nich zależni". Wtóruje mu Mirzoeff (1999, s. 7): „Można mówić o centralnym znaczeniu doznań wizualnych w życiu codziennym". Obrazy kształtują kulturę i przekazują wiedzę o społeczeństwie od czasów pierwotnych - wszak już malunki naskalne są skarbnicą wiedzy dla ludzi współczesnych. Nie można pomijać roli malowideł, obrazów, map, które obok druku i pisma, odzwierciedlają w dużym stopniu zwyczaje, prawa, zasady życia społeczeństw. Jednak prawdziwą rewolucją był wynalazek fotografii, a raczej jej upowszechnienie (przez aparaty fotograficzne, kserokopiarki aż po współczesne elektroniczne sposoby utrwalania i powielania obrazów). Odbiór, utrwalanie wiedzy, ale i przekaz treści płynących z tego zatrzymanego fragmentu rzeczywistości $\mathrm{w}$ zasadzie stał się nieograniczony. W ostatnich latach kultura wizualna zaczęła wręcz przeważać nad tekstami pisanymi, jak zauważa Sztompka (2005), jesteśmy otoczeni znakami drogowymi, piktogramami w miejscach użyteczności publicznej, codziennie oglądamy szyldy, reklamy i graffiti, a słuchając muzyki często oglądamy teledyski. To spostrzeżenie można zaktualizować o pismo obrazkowe (emotikony używane w komunikatorach), międzynarodowe gesty zastępujące często proste formy komunikacji, a nawet barwy. Obrazy konstruują i artykułują nasze postrzeganie świata, uzupełniaja, a czasem zastępują wrażliwość tekstową. W skrajnych przypadkach "coś porusza nas bardziej na fotografii, niż wtedy gdy doświadczamy tego realnie" (Sontag, 1978, s. 168). Sytuacja ta jest zauważana w opracowaniach dotyczących turystów, którzy są zawiedzeni rzeczywistym wyglądem miejsca, którego obraz uprzednio sobie wytworzyli na podstawie zdjęć, pocztówek i folderów reklamowych (np. Smith, 2003; MacCannell, 2011).
Dyrektor nowojorskiego Museum of Modern Art powiedział: „Fotografia to okno, ale także i lustro” (Magala, 2000). Zatem, badać można fotografa (dlaczego zrobił takie zdjęcie), treść zdjęcia (czyli sytuację, która została uwieczniona), albo odbiorcę fotografii, który być może „widzi” na niej coś innego. W niniejszych rozważaniach nie wykorzystano trzeciego sposobu analizy fotografii, a więc punktu widzenia odbiorcy obrazu. Wykonane przez respondentów fotografie zostały poddane analizie z punktu widzenia tego, kto je wykonał oraz tego co przedstawiają za pomocą czterech podejść interpretacyjnych (strukturalistycznego, hermeneutycznego, semiologicznego oraz geograficznego).

Do metod interpretacji fotografii zalicza się interpretację strukturalistyczną. Jest to podejście ilościowe, przekładające treść wszystkich fotografii na dane liczbowe. Co i w jaki sposób jest zliczane, zależy od celów badania. Obrazy zostają ocenione przez pryzmat opracowanych przez badacza kategorii i odpowiednio zakodowane. Takie podejście najlepiej sprawdza się jako typowa metoda ilościowa - zatem wskazane jest dysponowanie jak największą liczbą analizowanych fotografii. Lecz nawet przy mniejszej, jakościowej próbie (jak w niniejszym studium) można wyodrębnić pewne powtarzające się elementy, zjawiska i wzorce, które przy zachowaniu zasad takiej interpretacji (m.in. braku ekstrapolowania wyników na wszystkich badanych, gdyż nie mamy do czynienia z reprezentatywną próbą) może przynosić wartościowe wyniki. Typowym przykładem badań fotografii w turystyce, w których wykorzystano podejście strukturalistyczne są prace, m.in.: Milmana (2011) poświęcone analizie treści pocztówek z Turcji; Hsu i Song (2013) dotyczące treści magazynów podróżniczych czy wcześniejsze analizy autora (Duda, 2016), w których badano fotografie wykorzystane w katalogach biur turystycznych.

Podejście, w którym badacz skupia się na twórcy zdjęcia, nazywane jest analizą hermeneutyczną. W tym nurcie najważniejsze pytania, na które należy odpowiedzieć, to: kim jest autor? Dlaczego zrobił to zdjęcie? Co chciał przekazać? Z jakiej perspektywy społecznej patrzył? Jakie emocje mu towarzyszyły? Takich pytań można postawić mnóstwo, wszak „Nikt nie robi takiego samego zdjęcia tej samej rzeczy i domniemanie, że kamera dostarcza bezosobowego, obiektywnego obrazu, ustąpiło konstatacji, że fotografie [...] przedstawiają to, co jednostka postrzega" (Sontag, 1978, s. 88). Taka analiza, nawet przy zastosowaniu metodologicznej poprawności, tylko częściowo wyjaśnia rzeczywistość. Wiele interpretacji pozostanie subiektywnym odczuciem interpretatora, który mniej lub bardziej udanie "zrozumie" autora, a „zrozumieć to tyle co uchwycić znaczenie, jakie nadała mu intencja działającej jednostki, zadanie - jak łatwo zauważyć - zasadniczo różne od celów nauk przyrodniczych" (Bauman, 1978, s. 12). W pewnych przypadkach można skorzystać z pomocy 
przy interpretacji (albo potwierdzenia ex post) samego autora zdjęcia. W przypadku rozważań podjętych w tej pracy, technicznie byłoby to możliwe, lecz ostatecznie z tego zrezygnowano, gdyż rzadko w badaniach z turystami jest taka możliwość, a celem było testowanie sposobu badania, który docelowo ma służyć do zastosowania w różnych warunkach.

Trzecim podejściem - w którym przedmiotem interpretacji jest sam obraz - jest tzw. interpretacja semiologiczna. Semiologia to nauka o funkcjonowaniu znaków w społeczeństwie (de Saussure, 2002). Podstawowa idea interpretacji semiologicznej zakłada zatem, że „obraz jest znakiem lub sumą znaków, za którymi kryją się znaczenia kulturowe” (Sztompka, 2005, s. 81). Proces analizy wymaga uwzględnienia denotacji i konotacji zdjęcia. Denotacja to wszystko co obraz przedstawia - np. zrujnowana kamienica, a konotacja to jego znaczenie - w tym przypadku: przestrzeń niebezpieczna, ubóstwo, strach, brak perspektyw. Za prekursorską pracę w nurcie analizy zastanych fotografii należy uznać monumentalną Gender Advertisements E. Goffmana z 1979 r., w której na podstawie 508 zdjęć (głównie reklamowych i prasowych) badacz szukał konwencji kobiecości i męskości (albo raczej kulturowego wzorca tych pojęć) (Goffman, 1979). W przypadku fotografii mamy pewność (w przeciwieństwie do np. malarstwa) co do "prawdziwości” sytuacji (pominąć tu należy oczywiście fotomontaże), „denotacja jest bezpośrednia” (Barthes, 1983, s. 206). Wiemy, jakie symbole pojawiają się na wielu fotografiach - ale jakie niosą one przesłanie? Na to pytanie badacze próbują odpowiedzieć, stosując podejście semiologiczne. Znaczenie obiektu na zdjęciu dostrzegła też w badaniach Chlebuś-Grudzień (2018, s. 9), pisząc, że „fotografie mają zdolność nadawania wartości treściom na nich prezentowanym [...] gdyż ktoś to zauważył, uznał za ciekawe i zdecydował się utrwalić". Różni autorzy (m.in. Peirce, 1955; Barthes, 1983; Leon, 2017) stosowali wielorakie metody wyodrębnienia znaczenia poszczególnych elementów uchwyconych na fotografii.

Analiza geograficzna nie pojawia się w badaniach socjologicznych, gdyż dotyczy rozmieszczenia w przestrzeni, co zazwyczaj nie ma znaczenia z punktu widzenia tych badań. Jednak dla geografów analiza geograficzna jest bardzo istotna. Badacze związani z geografią intuicyjnie czuja, jak powinna ona wyglądać, wszak nie jest to pojęcie nowe - „podejście geograficzne (przestrzenne) zaowocowało wypracowaniem wielu ilościowych metod analiz przestrzennych wykorzystujących także socjologiczne badania ankietowe lub środowiskowe badania percepcji" (Kotus, Rzeszewski, 2015, s. 58). Różne sposoby badania szeroko rozumianych utworów graficznych w geografii można znaleźć choćby w pracach Lyncha i jego następców, dotyczących map mentalnych (Lynch, 1960; Gould, White, 1974). Innymi badaniami, które uwzględniały zarówno aspekt przestrzenny, jak i wizualny były m.in. badania nad wytyczeniem automatycznych tras zwiedzania miasta na podstawie algorytmu, opierającego się na danych z portalu Flickr (zawierającego zdjęcia ze wskazanymi współrzędnymi ich wykonania), przeprowadzone przez De Choudhury'ego i in. (2010). Wspomnieć warto również o przygotowanym przez Li (2013) algorytmie, który opierając się na dotychczas wykonanych przez turystów zdjęciach, sugeruje plan pobytu.

Nurt badań wykorzystujących współczesne technologie - głównie dane GPS zapisywane w metadanych pliku graficznego - jest jednym z najlepiej rozwiniętych we współczesnej geografii. Liczne prace na ten temat można znaleźć nie tylko w czasopismach geograficznych, ale także dotyczących informatyki, geoinformacji lub przetwarzania danych. Oprócz wymienionych wcześniej pozycji przykładami takich badań są m.in.: opracowania przygotowane przez: Kadar, Gede, 2014; Feick, Robertson, 2014; Kurashima, Iwata, Irie, Fujimura, 2013. Prac poruszających tę tematykę jest wiele - niniejsze opracowanie ma zaś pokazać, że podobna analiza jest możliwa również w przypadku braku danych geolokalizacyjnych, które ustalane są na podstawie treści zdjęcia przez badacza. Następnie analizy przeprowadza się standardowo dla danych przestrzennych za pomocą np. narzędzi GIS.

W rozumieniu autora $\mathrm{w}$ analizie geograficznej znaczenie mają także takie kwestie, jak np.: z jakiego miejsca w przestrzeni została wykonana fotografia - pod jakim kątem i w którym kierunku, jaka jest lokalizacja treści zdjęcia, jak daleki od autora zdjęcia jest fotografowany obiekt - czy znajduje się w znacznym oddaleniu czy jest blisko? W zależności od posiadanych dodatkowych informacji z innych źródeł badanie można kontynuować, analizując np., jak lokalizacja zdjęcia ma się do miejsca zamieszkania (albo pobytu w obiekcie noclegowym), kierunku przyjazdu do miasta itd. Pomocne mogą być również dane ogólnodostępne, np. relacja pomiędzy miejscami wykonania zdjęć a rozmieszczeniem największych atrakcji turystycznych na danym obszarze (jak w tym studium).

\section{METODA BADAŃ}

Jak wspomniano we wstępie, omówiona w tekście analiza fotografii jest częścią szerszych badań dotyczących wizerunku miasta, opartych na wywiadach swobodnych z turystami odwiedzającymi Łódź. Wywiady te prowadzone były trzykrotnie z tymi samymi osobami: przed przyjazdem do miasta, bezpośrednio po dwu- lub trzydniowym pobycie oraz powtarzane po dłuższym czasie od podróży (po dwóch lub trzech miesiącach). Ze względu na taki sposób prowadzenia badań badacz był w stałym kontakcie z respondentami, co stworzyło 
możliwość wprowadzenia dodatkowych elementów, takich jak niniejsza, eksperymentalna analiza fotografii.

W badaniu uczestniczyły 23 osoby w różnym wieku (autor przydzielił respondentów do grup osób w wieku: młodszym - do 30 lat, średnim - 30-55 oraz starszym - powyżej 55 lat), różniące się płcia, miejscem zamieszkania (od wsi, przez małe miasta, aż po największe polskie metropolie), wykonywaną pracą oraz wykształceniem. Respondenci podróżowali indywidualnie, rzadziej $\mathrm{w}$ parach oraz $\mathrm{w}$ jednym przypadku w towarzystwie żony i dzieci. Mieli inne zainteresowania oraz wcześniejsze doświadczenia podróżnicze (od emeryta wyjeżdżającego głównie na działkę poza miastem, po podróżników mających na swoim koncie kilkanaście wyjazdów zagranicznych).

Przed przyjazdem do Łodzi respondenci zostali poinstruowani, aby podczas pobytu (w miarę możliwości) wykonywali zdjęcia. Jedyną formą standaryzacji tego elementu, była informacja, że później zostaną poproszeni o przesłanie dwóch lub trzech zdjęć, które ,jjak najlepiej oddają ich pobyt". Autor, aby nie wpływać na treść materiałów, celowo unikał słów, które mogłyby w jakiś sposób określać zdjęcia (np.: najlepsze, najładniejsze, najbardziej szokujące itp.). Tym samym badani mieli całkowitą dowolność w wybieraniu obiektów, ich kadrowaniu oraz w ostatecznym wyborze obrazów, które prześlą jako swoje „podsumowanie pobytu”. Nie była to zatem w pełni spontaniczna obserwacja, mająca głównie sens heurystyczny (Sztompka, 2005), ale i nie całkowicie nakierowana na skupienie na danym zagadnieniu (w tym przypadku wizerunku), tak jak miało to miejsce np. w badaniach socjologicznych Roberta Lynda, w których badani za pomocą fotografii mieli odpowiedzieć na konkretne pytania (Suchar, 1989). Ostatecznie okazało się, że zadanie postawione przez autora niniejszego artykułu nie było trudne. Respondenci dostarczyli fotografie (stosując się do kryterium „najlepiej oddających pobyt"), które łącznie utworzyły zbiór 68 obrazów (22 osoby przysłały po 3 zdjęcia, a jedna osoba 2 ).

Analizę fotografii przeprowadzono z punktu widzenia czterech opisanych wcześniej podejść - strukturalistycznego, hermeneutycznego, semiologicznego oraz geograficznego.

Analiza geograficzna obejmowała pięć etapów:

1. Określenie miejsca wykonania fotografii.

2. Naniesienie na mapę lokalizacji miejsc wykonania fotografii.

3. Wpisanie punktów w heksagony o rozmiarze 3 ha, aby dokonać rangowania obszarów miasta pod względem popularności wśród autorów zdjęć.

4. Wytyczenie granic w odległości $250 \mathrm{~m}$ od każdego z punktów celem stworzenia minimalnego obszaru, który był eksplorowany przez turystów.

5. Naniesienie na mapę lokalizacji 15 największych atrakcji turystycznych miasta i interpretacja wyników.

\section{WYNIKI BADAŃ}

\subsection{STRUKTURALISTYCZNA ANALIZA TREŚCI}

Otrzymane od respondentów fotografie zostały poddane analizie treści, zbiorczo dla całej badanej grupy turystów. Każde z otrzymanych 68 zdjęć zostało dokładnie przeanalizowane pod kątem zawartości. Opracowano 13 kategorii, w ramach których każde zdjęcie zostało przypisane do jednego $z$ wariantów kodowania. W poniższej tabeli (tab.1) przedstawione zostały kategorie, warianty oraz procentowy podział fotografii według nich.

Tabela 1. Kategorie i warianty oceny zdjęć pod kątem strukturalistycznym

\begin{tabular}{|l|l|}
\hline \multicolumn{1}{|c|}{ Kategoria } & \multicolumn{1}{c|}{ Warianty kodowania } \\
\hline Główny obiekt na zdjęciu & element na budynku (32\%), ulica (2\%), budynek (21\%), ludzie (6\%), przyroda (4\%), inne (12\%) \\
\hline Ludzie na zdjęciu & brak (56\%), więcej niż 3 os. (29\%), 2-3 os. (9\%), 1 os. (6\%) \\
\hline Rodzaj ludzi na zdjęciu & nie dotyczy (56\%), obcy ludzie (35\%), rodzina (4\%), autor (3\%) \\
\hline Horyzont zdjęcia & panorama (43\%), bliski (28\%), średni (18\%), bardzo bliski (12\%) \\
\hline Łódzki obiekt & ul. Piotrkowska (19\%), Pasaż Róży (10\%), Manufaktura (9\%), inny (62\%) \\
\hline Wydźwięk zdjęcia & pozytywny (46\%), trudno powiedzieć (19\%), mieszany (12\%), negatywny (9\%) \\
\hline Pora dnia & dzień (80\%), noc (13\%), nie dotyczy (7\%) \\
\hline Wydarzenie & brak (91\%), „Light.Move.Festival” (8\%), inne (1\%) \\
\hline $\begin{array}{l}\text { Powtarzalność obiektu wśród } \\
\text { innych zdjęć }\end{array}$ & powtarza się (24\%), nie powtarza się (76\%) \\
\hline Dynamika zdjęcia & statyczne (66\%), dynamiczne (34\%) \\
\hline Cegła & występuje (38\%), nie występuje (62\%) \\
\hline Napisy na zdjęciu & występują (31\%), nie występują (69\%) \\
\hline Element sztuki & występuje (60\%), nie występuje (40\%) \\
\hline
\end{tabular}

Źródło: opracowanie własne na podstawie badania. 
Badania pokazały, że biorąc pod uwagę porę wykonania zdjęć, to większość (80\%) z nich została zrealizowana za dnia - pozostałe zostały zrobione we wnętrzu budynku (zazwyczaj jakiegoś muzeum - ze względu na brak możliwości oceny pory dnia, takie zdjęcia zostały oznaczone jako „nie dotyczy”) lub w nocy. Fotografie wykonane nocą związane są głównie z festiwalem "Light.Move.Festival”, który odbywa się po zmroku. Wniosek, który nasuwa się na podstawie tych danych, jest następujący - turyści zwiedzają Łódź głównie w ciągu dnia i w godzinach otwarcia większości atrakcji turystycznych. Mimo przebywania poza miejscem zakwaterowania także po zmroku (co wynika z wywiadów), uznali, że pobyt najlepiej oddadzą „dzienne zdjęcia". W tym przypadku należy również uwzględnić letnią porę pobytu respondentów, a tym samym dłuższy dzień. Zdjęcia wykonane za dnia są wyraźniejsze i więcej pokazują - mogło to wpływać na decyzję respondentów o wyborze danej fotografii.

Na zdjęciach zazwyczaj uwieczniona jest zabudowa miejska - w ponad połowie przypadków bez ludzi w kadrze. Jeżeli jednak sfotografowani zostali ludzie, to są nimi grupy przechodni na ulicy. Obrazy, które obejmują jedną lub dwie osoby stanowią rzadkość. Brak ludzi na zdjęciach jest typowy dla fotografii podróżniczych - autor chce w ten sposób przede wszystkim pokazać miejsce. Turyści podświadomie dążą do robienia zdjęć przypominających pocztówki lub foldery turystyczne - na których raczej nie ma przechodniów (Duda, 2016; Wieczorkiewicz, 2012). Wydawane są nawet poradniki z instrukcjami, jak wykonać zdjęcie obiektu bez ludzi w kadrze. Zaskakuje niewielka liczba zdjęć uwieczniających autorów lub autorów z rodziną bądź z osobami z nimi podróżującymi - jest to zaledwie 6 fotografii na 68 przesłanych. Można przypuszczać, że fotografii takich powstało więcej, lecz nie zostały przesłane do analizy.

Szczególnie interesujące jest zestawienie głównych obiektów na zdjęciu. Najczęściej fotografowano element budynku - napis, mural, ozdobę lub detale architektoniczne. Zdjęcia, na których widać szerszy kadr - kilku budynków i ulicy, były na drugim miejscu pod względem najczęściej wybieranych ujęć. Budynki i zabytki były obiektem co piątego zdjęcia. Z kolei bardzo rzadko uwieczniana była przyroda, niewiele jest również fotografii ludzi. Do zbioru fotografii nazwanego „inne” zaliczono wszystkie zdjęcia niepasujące do poprzednich kategorii - np. pomniki, przedmioty, pojazdy itp. Rodzaj obiektów uwiecznionych na fotografiach ma sens z punktu widzenia chęci „pokazania miasta" - w rozumieniu respondentów, miasto to przede wszystkim ulice i budynki. Duża liczba sfotografowanych „elementów na budynku” wynika z tego, że podróżni uznali te rzeczy z warte uwiecznienia, zaskoczyły ich i zaciekawiły, były inne od znanych im dotąd obiektów. Zabudowa w wielu polskich miastach jest do siebie dość podobna - stąd, jak można sądzić, tak wiele zdjęć elementów charakterystycznych, nietypowych i nowych dla turystów. Niewielka liczba sfotografowanych obiektów przyrodniczych może świadczyć o centralnej lokalizacji pobytu (w centrum i śródmieściu Łodzi jest stosunkowo niewiele terenów zielonych) lub o marginalizowaniu znaczenia roślinności w mieście (stereotypowo - miasto to nie przyroda).

Uwzględniając inną badaną cechę - odległość fotografowanego obiektu od autora zdjęcia, to w blisko połowie przypadków był to relatywnie duży dystans, umożliwiający ujęcie panoramiczne.

W większości przypadków sfotografowane obiekty nie powtarzały się na zdjęciach innych respondentów (cztery na pięć zdjęć), bliźniaczo podobne kadry lub określone miejsca zostały uwiecznione 16 razy. Miejscem, które najczęściej wybierali respondenci do sfotografowania była ul. Piotrkowska. Zdjęcia zostały wykonane na różnych odcinkach, lecz pewne zagęszczenie występuje w okolicach tzw. Pasażu Róży (podwórka pod nr. 3) i „Off Piotrkowska”. Kilka zdjęć zostało także wykonanych w Manufakturze. Analiza miejsc, w których turyści wykonywali fotografie, pozwala na uzyskanie informacji na temat przestrzeni odwiedzanych przez turystów (zob. więcej podrozdz. 4.4).

Elementami, które powtarzały się często na obrazach, były napisy i cegła (o której respondenci dopowiadali w wywiadach). Napisy (szyldy, murale, graffiti) pojawiają się na jednej trzeciej wszystkich zdjęć, zaś cegła - w blisko co drugim przypadku. Napisy często są zaskakujące, zabawne lub w jakiś sposób komentują rzeczywistość, czym prawdopodobnie zwróciły uwage turystów i zachęciły do zapisania tej sytuacji w formie obrazu. Cegła zaś, charakterystyczna dla architektury wielu łódzkich atrakcji, musiała zostać w pamięci - stąd prawdopodobnie wybór takich zdjęć - gdyż w mniemaniu respondentów „to właśnie Łódź”.

Detalem wspólnym, powtarzającym się na więcej niż połowie fotografii - jest obecność szeroko rozumianej sztuki. Są to murale, rzeźby, instalacje artystyczne, graffiti. To dosyć zaskakujące, ale tożsame z wypowiedziami i wspomnieniami respondentów, w których podkreślano „klimat”, ,artystyczną duszę” i „inność miasta".

Na większości fotografii (62 na 68) nie zostały sfotografowane wydarzenia czy imprezy. Wyjątkami sa fotografie pokazów odbywających się w ramach „Light. Move.Festival” (5 przypadków) i koncertu na ul. Piotrkowskiej (1 przypadek). Widać więc, że wydarzenia i sytuacje zmienne według respondentów gorzej oddają „duszę miasta” niż stałe obiekty. Tezę tę potwierdza również podział fotografii w kategorii „dynamika zdjęcia”, w której wyróżniono zdjęcia: statyczne - dwie trzecie ogółu i dynamiczne - jedna trzecia ogółu. Za dynamiczne uznane zostały wszystkie obrazy, na których widać ruch - poruszający się tłum, falujące na wietrze 
ozdoby albo trwający pokaz multimedialny. Wynika z tego, że większą uwagę przyciągnęły sytuacje trwałe i uniwersalne dla danego miejsca.

\subsection{INTERPRETACJA HERMENEUTYCZNA}

Oprócz tego, co zdjęcie konkretnie przedstawia, nie można pominąć osoby twórcy - autora. Wpływ mają jego cechy osobowościowe, nastrój, pochodzenie, cel, w którym wykonał zdjęcie i dziesiątki innych zmiennych, których nie sposób przewidzieć.

Narzędziem pomocnym przy interpretacji hermeneutycznej jest empatia i „postawienie się w wyobraźni w roli autora zdjęcia, wczucie $w$ jego sytuację [...]" (Sztompka, 2005, s. 79). Interpretacje takie są trudne i obarczone pewną dozą niepewności, zwłaszcza gdy autorami są osoby nieznane badaczowi. W tym przypadku pomocne było główne narzędzie badawcze, czyli wywiad pogłębiony. Dzięki trzem długim rozmowom (na różnych etapach podróży), zyskano wiele cennych informacji, wychodzących poza zakres standardowej metryczki. Badani często mimochodem wspominali o zainteresowaniach, pracy lub dotychczasowych doświadczeniach czy wspomnieniach.

Ze szczególną uwagą autor przyjrzał się kilku przypadkom. Pierwszym z nich są zdjęcia respondenta, który wcześniej był w Łodzi na szkoleniu i miasto zrobiło na nim przygnębiające wrażenie (fot. 1). Do ponownego przyjazdu (tego objętego wywiadami) był uprzedzony, miał zdecydowanie najgorsze wyobrażenia o Łodzi spośród wszystkich respondentów.

Zdjęcie przesłane przez tego respondenta (fot. 1) przedstawia budynek podpierany stelażem chroniącym przechodniów przed odpadającymi kawałkami elewacji. Wśród wszystkich zdjęć niewiele było tych nacechowanych negatywnie lub pokazujących nieatrakcyjne elementy (ok. 10 przypadków) - a za takie trzeba uznać fotografię ruiny. Świadczyć to może o chęci respondenta do "wyszukiwania” obrazów potwierdzających negatywne przekonania i wspomnienia. Słowa badanego, będące niezamierzonym komentarzem, są potwierdzeniem powyższej tezy: „nawet miejsce, gdzie my tam spaliśmy, w tym hotelu i okolicach to same poniszczone budynki, w ogóle nie wyglądało to na jakieś miejsce, które jest oddalone, nie wiem, dwa kilometry od centrum, czy nawet o półtora kilometra" (Respondent nr 7-zob. załącznik 1).

Uwagę badanego mężczyzny przykuły zatem elementy negatywne lub maskujące negatywy. Było to na tyle ważne, że respondent zrobił im zdjęcia oraz wybrał je jako "reprezentujące pobyt". Zdjęcia wykadrowane są w taki sposób, aby pokazać ten jeden, główny element/budynek. Nie ma na nich ludzi, żadnej dynamicznej sytuacji ani wydarzenia. Może to świadczyć o spokojnym i przemyślanym wyborze kadrów - na

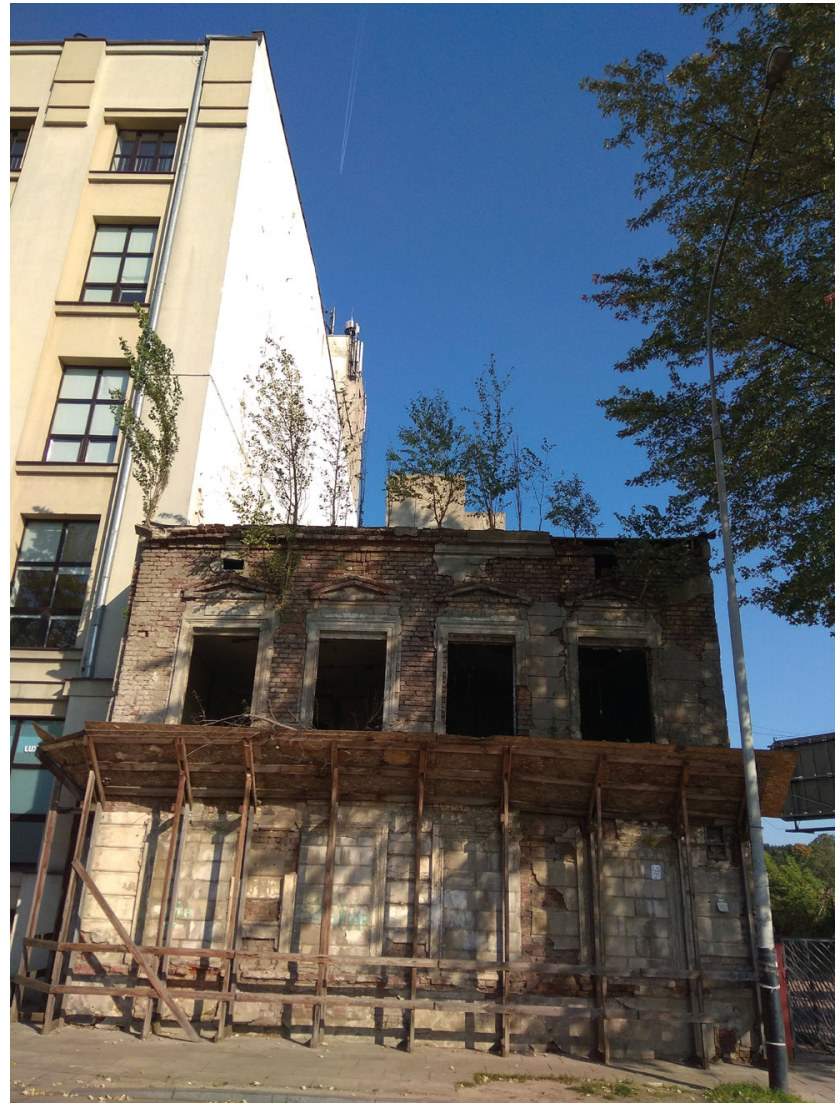

Fotografia 1. Zrujnowany budynek Źródło: Respondent nr 7

zasadzie dokumentacji potwierdzającej wcześniejszą opinię.

Innym przykładem są zdjęcia respondenta, który przyjechał do Łodzi wraz z rodziną. Na podstawie jego zdjęć także odczytać można pewne prawidłowości. Na potrzeby artykułu wybrano jedno zdjęcie tego respondenta (fot. 2), które, podobnie jak inne przez niego wykonane, przedstawia dzieci autora podczas pobytu w mieście. To typowa fotografia rodzinna, dokumentująca "funkcję rodzinna, a dokładniej funkcję nadaną jej przez grupę rodzinną i polegającą na uświetnieniu i uwiecznieniu doniosłych momentów życia rodziny"

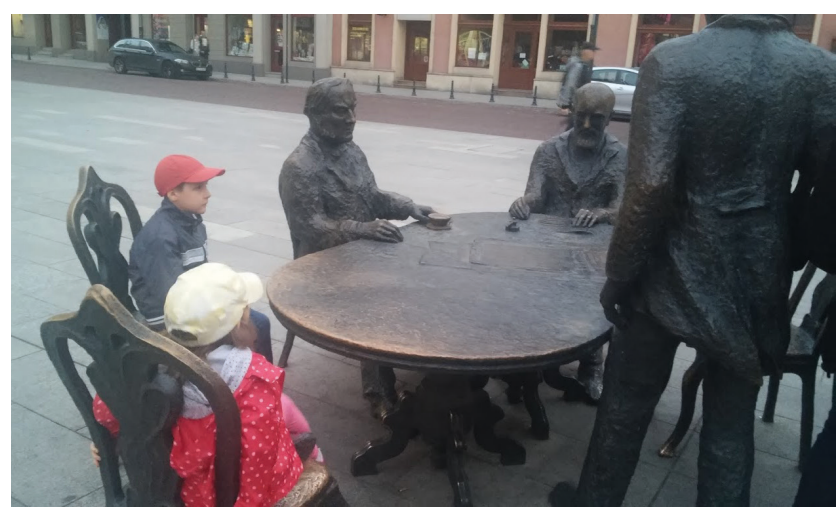

Fotografia 2. Zdjęcie przy Pomniku Wielkich Łodzian Źródło: Respondent nr 19 
(Bourdieu, 1990, s. 19). Zdjęcia, na których są osoby odbywające podróż, to rodzaj pamiątek, „dowód, że tam byliśmy, że zwiedziliśmy te słynne miejsca" (Sztompka, 2005, s. 65). Na fotografiach nie ma jednak całej rodziny, wyłącznie dzieci. Być może autorowi przyświecała chęć zrobienia fotografii, które w przypomnieniu pobytu mają pomóc głównie najmłodszym, którzy mogą gorzej zapamiętać wyjazd niż rodzice? Albo są wyrazem charakteru pobytu lub szerzej - bycia rodzicem, który podróżowanie i zwiedzanie podporządkowuje opiece i zadowoleniu dzieci. Kadry nie są przypadkowe, to sytuacje, w których dzieci są zajęte (w tym przypadku siedzeniem „razem” z fabrykantami), a rodzic-autor ma chwilę wytchnienia i może wyciągnąć aparat.

Kolejnymi przykładami są fotografie technicznie bardzo do siebie podobne. Pierwsze zdjęcie zostało wykonane przez respondentkę zajmującą się hobbystycznie fotografią (fot. 3), a drugie przez podróżników, prowadzących amatorsko blog turystyczny (fot. 4).

Oba te obrazy są "artystyczne”, bardziej przemyślane niż spontaniczne i niepozowane. $W$ pierwszym przypadku widać zabawę odbiciem, chęć przekazania

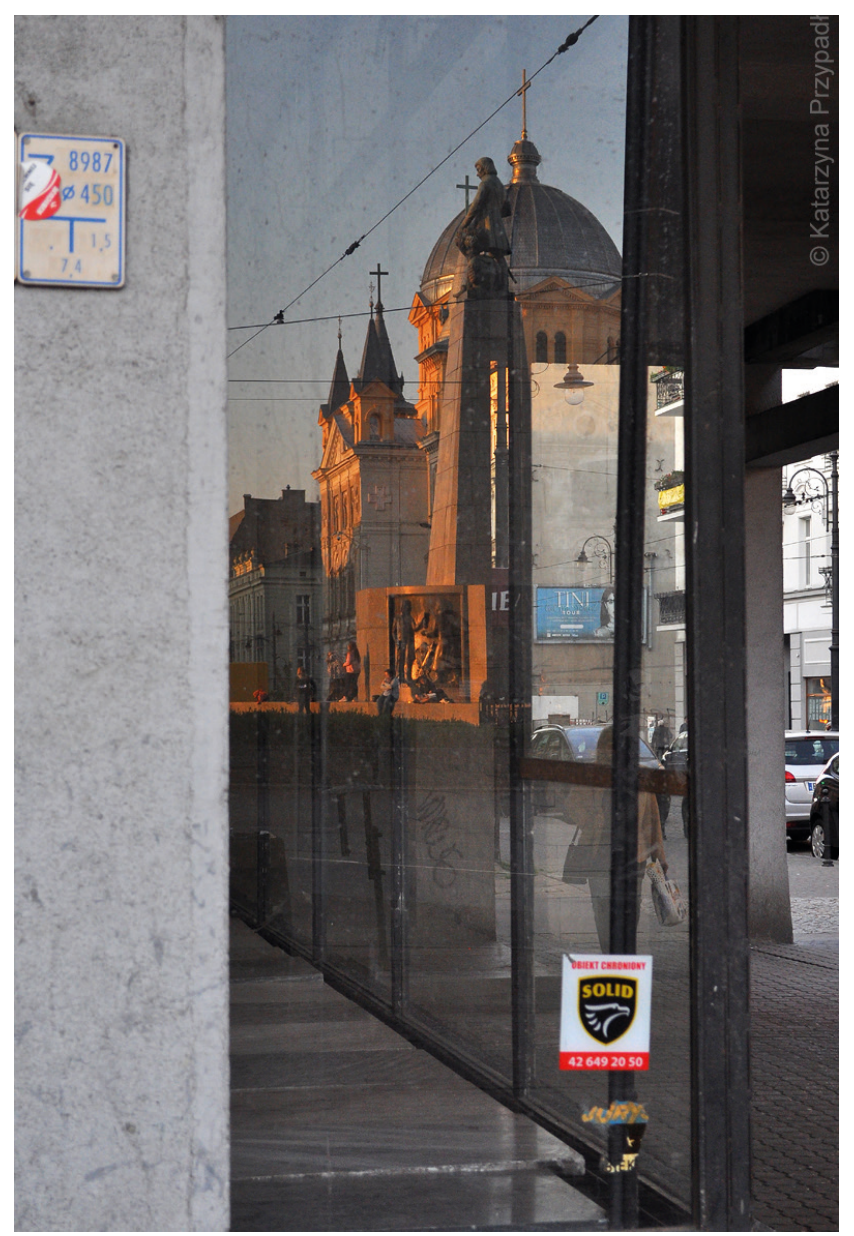

Fotografia 3. Odbicie kościoła pw. Zesłania Ducha Św. w szybie sąsiedniego budynku Źródło: Respondentka nr 18

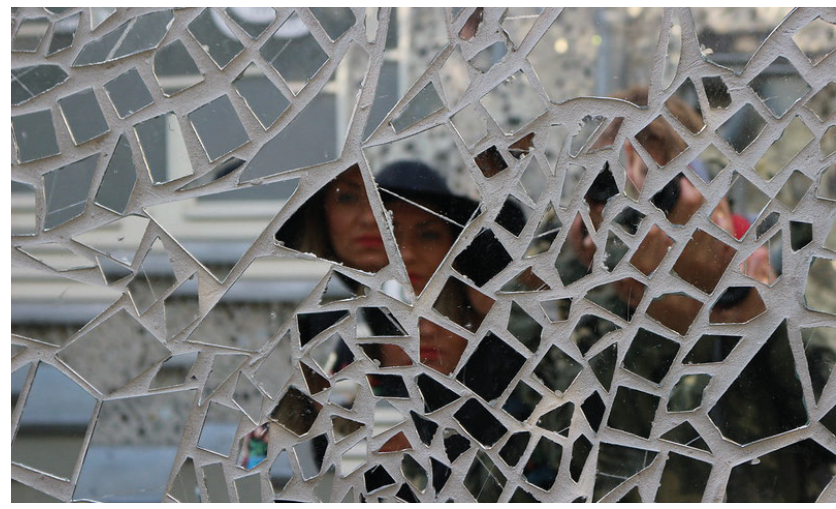

Fotografia 4. Odbicie autorów w lustrzanej elewacji „Pasażu Róży”

Źródło: Respondent nr 17

fotografią jakiegoś przesłania. Druga fotografia (fot. 4) prawdopodobnie powstała też z myślą o publikacji na blogu - tym samym jej wykonaniu od początku przyświecał pewien cel. Autorzy wykorzystali lustrzaną powierzchnię, również do uwiecznienia w niecodzienny sposób siebie, dzięki temu obraz jest zaskakujący, nietuzinkowy i przyciągający uwagę. Fotografie te pełnią różne funkcje, od zwykłej dokumentacji, przez pewną formę autoprezentacji (a może nawet Goffmannowskiej autokreacji), aż po próbę budowy prestiżu poprzez nadanie obrazowi ",artystycznego sznytu”, mającego naśladować prace profesjonalnych fotografów. Zaliczyć je też trzeba do typowych zdjęć turystycznych - będących pamiątką („relikwią z innej rzeczywistości” - Edwards, 1997, s. 62) oraz dowodem na odbycie podróży (wpisując się tym samym w konsumpcyjną kulturę, w której „zawłaszczamy miejsca”, o czym pisał np. Fromm, 2003).

Fotografie kolejnego respondenta (fot. 5. i fot. 6) należy analizować równocześnie. Uznać je trzeba bowiem za „mini fotoesej”, próbę krótkiej opowieści - według turysty wyjaśniającej więcej niż pojedyncze zdjęcie. W tym przypadku miała też miejsce niecodzienna w tych badaniach sytuacja - nazwy plików ze zdjęciami były swego rodzaju komentarzem i wskazówką dla badacza, jak interpretować ten materiał.

Tytułowanie zdjęć przez respondenta budzi skojarzenia ze spostrzeżeniami Barthes'a (1977), który taki zabieg widział jako analogię z komiksowym dymkiem lub filmowym dialogiem (np. w kinie niemym). Zdjęcia są podobne, ale też skrajnie różne. Oba przedstawiają zwykłą łódzką ulicę, w takich samych warunkach pogodowych (prawdopodobnie zostały wykonane jednego dnia), bliźniacza jest też perspektywa i kompozycja. Na tym jednak podobieństwa się kończą. Na pierwszym zdjęciu (fot. 5) widać szarość zaniedbanych kamienic, sznur zaparkowanych samochodów, graffiti i bałagan. Druga, kontrastowa fotografia (fot. 6) przyciąga uwage pomarańczowym kolorem cegły, estetyka, pozytywnym nastrojem i przypomina wręcz pocztówkę. Interpretowanie ich pojedynczo mogłoby 


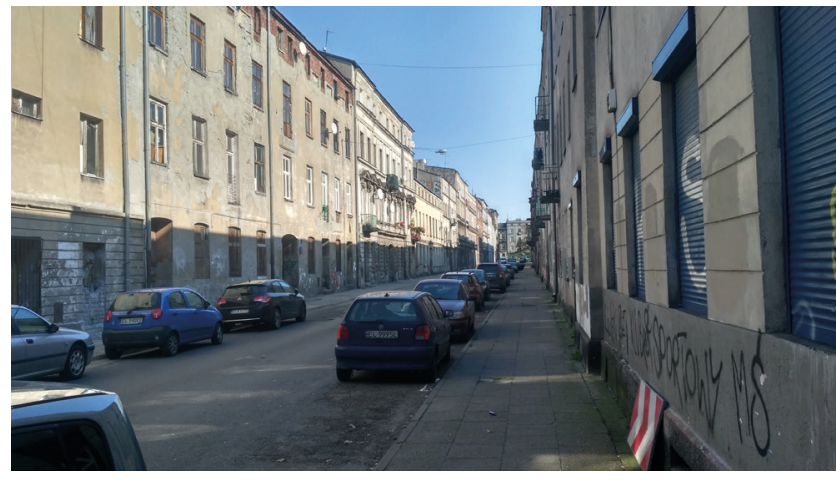

Fotografia 5. „Kontrast A.jpg” Źródło: Respondent nr 20

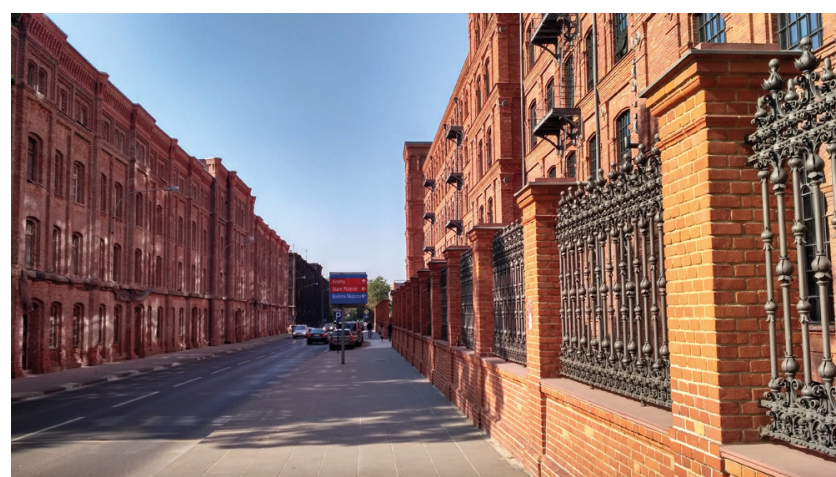

Fotografia 6. „Kontrast B.jpg”

Źródło: Respondent nr 20

prowadzić do sprzecznych wniosków, zaś zestawione razem oraz opatrzone niepozostawiającym złudzeń podpisem przedstawiają odczucia respondenta $\mathrm{w}$ stosunku do miasta. Podobieństwo obu obrazów sugeruje, że już podczas pobytu i wykonywania zdjęć turysta planował nimi odzwierciedlić swoje spostrzeżenia. Fotografie są przemyślaną emanacją spontanicznego poczucia „kontrastowego miasta”.

Przytoczone przykłady pokazuja, że proces tworzenia się wizerunku miasta u turystów-odbiorców to sprawa bardzo indywidualna i zależy od ogromnej liczby zmiennych (czasem losowych), które są trudne do uchwycenia i nieprzewidywalne.

\subsection{INTERPRETACJA SEMIOLOGICZNA}

Zupełnie inny sposób analizy fotografii proponuje się $\mathrm{w}$ podejściu semiologicznym, w którym na fotografię należy patrzeć nie przez pryzmat twórcy, a w zupełnym od niego oderwaniu.

Uczucia i spostrzeżenia turystów dotyczące zwiedzanego miasta przekazują powtarzające się lub schematyczne wzorce na fotografiach. Zbiorcze, strukturalistyczne przeanalizowanie ich, pozwoliło na wyodrębnienie kilku znaków, którym warto się przyjrzeć. Takimi znakami były powtarzające się na relatywnie dużej liczbie fotografii: elementy sztuki ulicznej, cegła, brak ludzi, napisy na murach, budynki, kontrastowe ujęcia.

Sfotografowane obiekty sztuki ulicznej, jak np. instalacje artystyczne (fot. 7) lub niecodzienne rzeźby (fot. 8), to obiekty zaskakujące w przestrzeni miejskiej. Odróżniają się od standardowych budynków i przyciągają uwagę. Symbolizują odmienność miasta od tradycyjnego wzorca, a także pokazują mniej poważne oblicze budynków, dekadencką nutę.

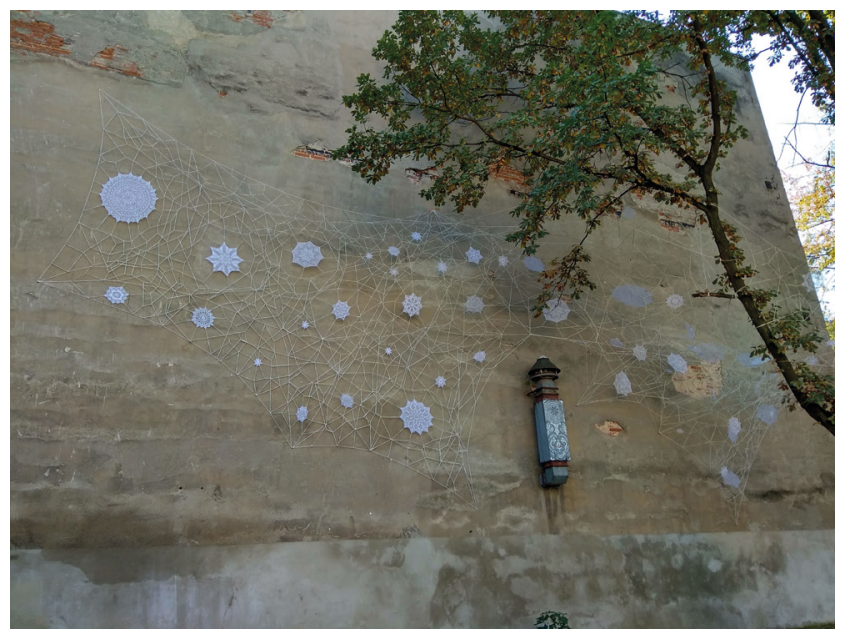

Fotografia 7. Koronkowa instalacja artystyczna na szczytowej ścianie jednej z kamienic Źródło: Respondent nr 10

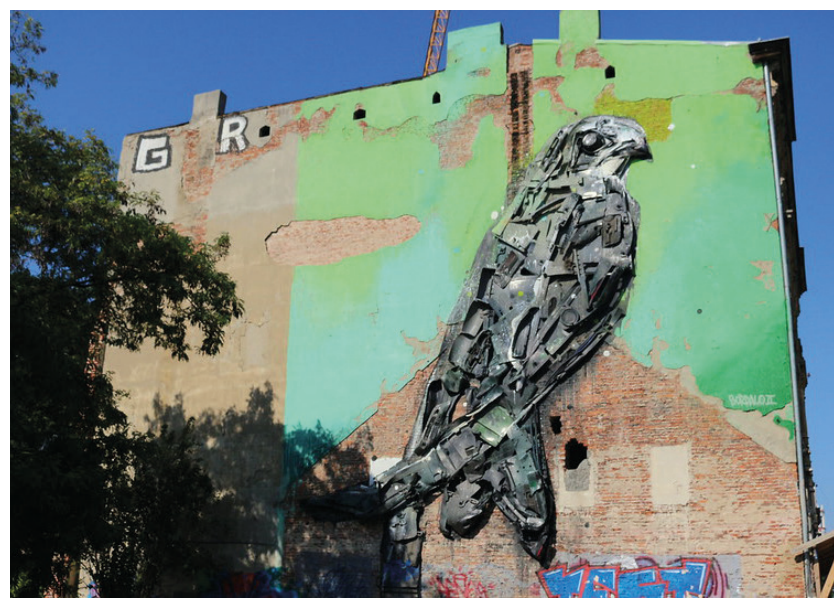

Fotografia 8. Instalacja artystyczna z części samochodowych na szczycie opuszczonej kamienicy Źródło: Respondent nr 23

Duża liczba zdjęć szeroko rozumianej sztuki (głównie ulicznej) może wskazywać na emocje jakie towarzyszyły turystom. Najwyraźniej podczas zwiedzania Łodzi zwrócili uwagę na liczną obecność takich działań w przestrzeni miejskiej i uznali (być może zachwycając się), że uwiecznienie ich "dobrze odda pobyt” w mieście. W wywiadach często podkreślano rolę takich dzieł i pojawiały się głosy, że to właśnie sztuka może być atrakcją Łodzi: 
Przemysłu, awangardy, sztuki. Tego nie mamy w żadnym polskim mieście. Tak mi się wydaje, bo w Krakowie na przykład, weźmy pod uwagę Kraków, no bierze się na kulturę i sztukę wysoką, ale brakuje tego czegoś jeszcze. A Łódź wydaje mi się, że mogłaby uzupełnić tą pustą przestrzeń (Respondent nr 20).

Murale to symbol walki z szarościa, upadkiem miasta i zrujnowaniem. Próba ożywienia smutnych przestrzeni. Poniekąd jest to metafora trudnych potransformacyjnych losów miasta. Turyści prawdopodobnie widzą w muralach nadzieję na zmianę sytuacji miasta i naprawę zaniedbań. Nikt w wywiadach nie krytykuje pomysłu takiego „ożywiania” ścian - wręcz przeciwnie, często podkreślano, że obrazy na ścianach budynków nadają miastu koloryt i tworzą niepowtarzalny klimat. Jednocześnie każdy z respondentów zauważa tło muralu - najczęściej elewację lub budynek po przejściach. W fotografiach murali przesłanie to jest czytelne - połączenie zaniedbania i zrujnowania, z kontrastowa, często kolorową energią. Z kolei z fotografii różnych napisów, np. graffiti pseudokibiców, można wyczytać zaskoczenie, zdziwienie i być może rozbawienia autorów zdjęć (fot. 9).

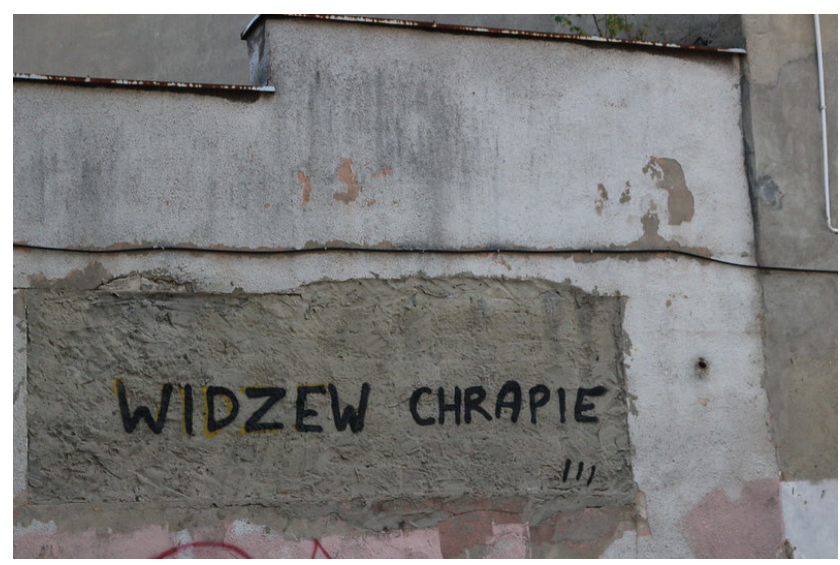

Fotografia 9. Graffiti nawiązujące do animozji pomiędzy kibicami łódzkich drużyn piłkarskich Źródło: Respondent nr 17

Napisy pełnią w pewnym sensie formę komentarza, ubarwienia fotografii wypowiedzią. Słowo pisane jest w tym przypadku substytutem słów, których nie przekaże obraz. Oczywiście nie można traktować ich dosłownie, ale jako metaforę lub trudne do uchwycenia przesłanie, którego treścią, oprócz „inności” Łodzi, jest kreatywność, dowcip twórców (postrzegany być może jako dowcip mieszkańców) oraz znów „walka z szarością" i nieprzyjemną rzeczywistością miasta.

Potwierdzeniem oczekiwań uczestników badania sprzed przyjazdu do Łodzi są obrazy skupiające się na ceglanych elewacjach. To symbol przemysłu, miejskich fabryk, historii. Jednocześnie, odnowiona i odczyszczona cegła (fot. 10) pokazuje powiązanie współczesności $\mathrm{z}$ historią oraz podkreślaną przez kilku responden- tów synergię dziedzictwa i nowych funkcji. Turyści doceniają że w mieście nawiązuje się do korzeni i wykorzystuje stare budynki do tworzenia nowego, oryginalnego oblicza Łodzi.

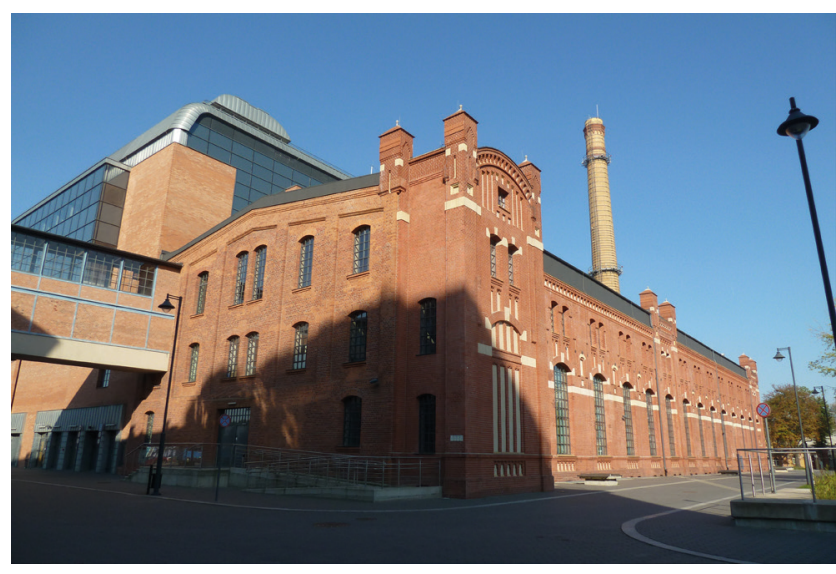

Fotografia 10. Hala maszyn dawnej Elektrociepłowni EC1, aktualnie centrum kulturalne Źródło: Respondent nr 11

Nie mniej ciekawą symbolikę mają zdjęcia, na których nie ma ludzi (fot. 11 i 12) - obrazy te pokazuja, że nadal istotne jest "tradycyjne" postrzeganie miasta - głównie utożsamianie miasta z trwałymi budowlami. Chęć zrobienia fotografii bez ludzi, to dążenie do zdjęć "pocztówkowych”, w których nic nie odwraca uwagi od obiektu zainteresowania - budynku. Puste przestrzenie mogą nieść też negatywne skojarzenia - np. z miastem wymarłym, opustoszałym, niegościnnym lub wręcz przeciwnie symbolizować spokój, majestat, brak gorączkowego napięcia i krzątaniny charakterystycznej dla obleganych turystycznych miejsc. Ogromne, puste place (jak ten przed nowo wybudowanym dworcem Łódź Fabryczna na fot. 11) mogą wywoływać lęk bądź onieśmielenie wśród turystów (zwłaszcza z mniejszych miejscowości), dla których rozmach i wielkość zabudowań dużego miasta może wydawać się przytłaczająca. Na przesłanych zdjęciach zazwyczaj uwieczniano

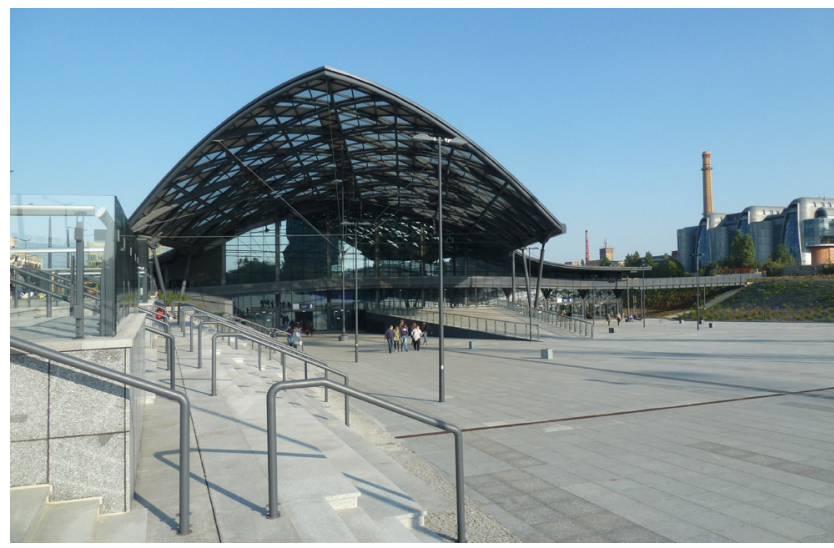

Fotografia 11. Plac przed dworcem Łódź Fabryczna Źródło: Respondent nr 1 


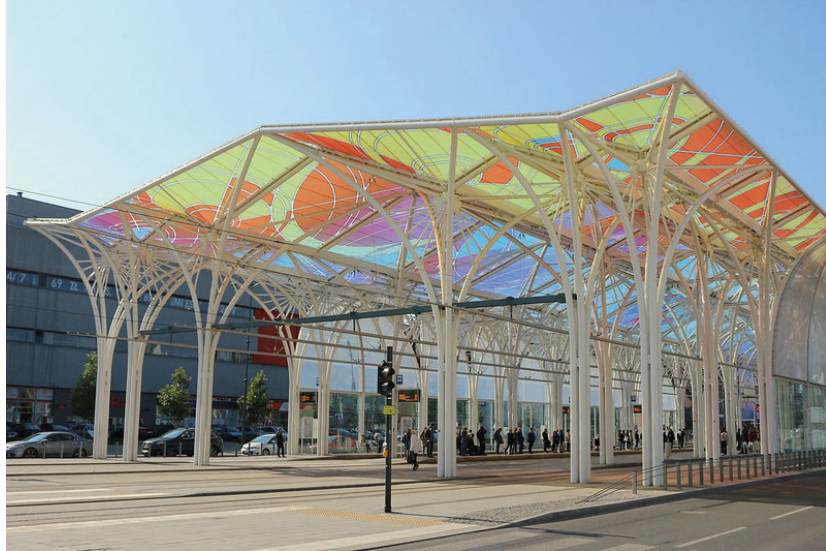

Fotografia 12. Przystanek tramwajowy Piotrkowska Centrum Źródło: Respondent nr 10

charakterystyczne gmachy i reprezentacyjne budowle. Miasta ciągle postrzegane sa przez pryzmat „łatwych do zapamiętania" budynków, które odróżniają je od innych miejsc. Tym samym następuje u odbiorców redukcja wizerunku miasta do kilku symboli. Nie dziwi więc, że takie fotografie zostały wybrane jako swoista wypowiedź turystów na temat tego, jak widzą odwiedzone miasto.

\subsection{ANALIZA GEOGRAFICZNA}

Ostatnim ze sposobów analizy fotografii jest analiza geograficzna, która pokazuje rozmieszczenia miejsc, w których wykonano zdjęcia w formie punktów na mapie miasta. Podejście jest swoistym substytutem badań, polegających na dokładnym śledzeniu (np. za pomocą GPS) ścieżki przemieszczania się turystów (zob. Kotus, Rzeszewski, 2015; Shoval, Isaacson, 2010). Zdjęcia wykonane zostały w rzeczywistej przestrzeni, zatem są dowodem, że autor również fizycznie musiał znaleźć się w tym miejscu. Miejsca wykonania wszystkich 68 fotografii zostały naniesione na mapę Łodzi. Fotografie zostały zrobione na stosunkowo niewielkim obszarze, w ścisłym centrum miasta (rys. 2).

Strukturalistyczna analiza treści pokazała, że najczęściej fotografowano ul. Piotrkowską. Jednak dopiero rozmieszczenie na mapie wszystkich wykonanych zdjęć pokazuje znaczenie tego obszaru dla turystów. Większość fotografii została wykonana w osi ul. Piotrkowskiej bądź w jej bezpośrednim sąsiedztwie. Kolejnymi obszarami, w których często były wykonywane zdjęcia, są okolice Manufaktury, okolice dworca Łódź Fabryczna oraz pofabryczne osiedle Księży Młyn. Tylko jedno miejsce wyraźnie odbiega od schematu - to fotografia wykonana na Nowym Cmentarzu Żydowskim - z dala od ścisłego centrum miasta. Poza cmentarzem wszystkie fotografie były zrobione w obrębie obszaru określonego w dokumentach strategicznych miasta jako strefa wielkomiejska. To strefa której „,[...]

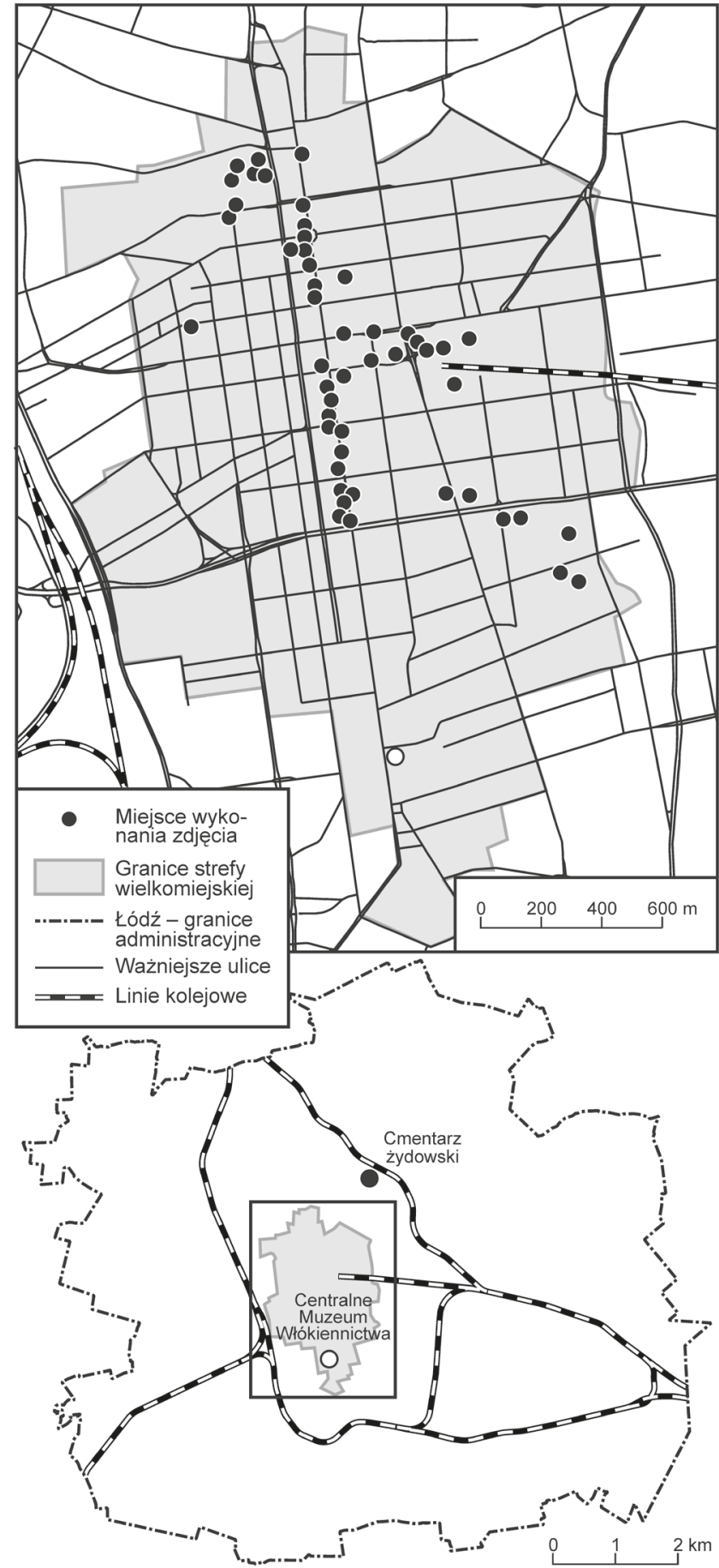

Rysunek 2. Lokalizacja miejsc wykonania fotografii przez respondentów na obszarze Łodzi

Źródło: opracowanie własne na podstawie badania

charakter decyduje o tożsamości Miasta. Jest najstarszą strukturą miejską Łodzi, najlepiej ukształtowaną urbanistycznie, zawierającą najwięcej okazałych budynków mieszkalnych i fabrycznych oraz regularnie i najpełniej zabudowanych kwartałów" (Strategia Rozwoju Łodzi 2020+, 2020).

Rozmieszczenie miejsc wykonania fotografii $\mathrm{w}$ formie punktów na mapie jest próbą oszacowania obszaru najważniejszego z perspektywy kształtowania 
się wizerunku turystycznego miasta. Należy pamiętać jednak o trzech zastrzeżeniach co do tej drogi postępowania:

- Badacz dysponuje tylko wybranymi fotografiami (uznanymi przez respondentów za „najlepiej oddające pobyt w mieście”). Być może, pełniejsza informacja płynęłaby z analizy wszystkich wykonanych fotografii, ale dzięki temu, że autorzy sami dokonali wyboru, obraz jest bardziej przemyślany i najtrafniej oceniający miasto.

- Nie można w dokładny sposób określić całej eksplorowanej przez turystów przestrzeni. Na podstawie samych fotografii nie sposób prześledzić dróg przemieszczania się po mieście ani docierania do kolejnych punktów - miejsc, które zrobiły na odbiorcy wrażenie godne uwiecznienia na zdjęciu.

- Powstały obraz jest agregacją lokalizacji zdjęć wszystkich respondentów, a zatem jest obrazem zbiorczym i znacznie obszerniejszym niż przestrzeń rozpatrywana indywidualnie dla każdego uczestnika badania. Trzeba założyć, że część przestrzeni została fizycznie odwiedzona przez wielu respondentów, a część zapewne wyłącznie przez pojedyncze osoby. Przy większej liczbie analizowanych fotografii, pochodzących od większej liczby badanych, różnice te uległyby znacznemu zwiększeniu, lecz z drugiej strony, można by dokładniej wytypować najczęściej fotografowane miejsca.

Próbując wyznaczyć najważniejszą dla wizerunku miasta strefę, autor skorzystał z metody stosowanej np. przy wyznaczaniu przez miasto strefy wielkomiejskiej, strefy rewitalizacji, obszarów słabości społecznej itp. Cały obszar miasta został podzielony na heksagony o powierzchni 3 ha. Heksagon w przeciwieństwie do kwadratu czy prostokąta lepiej wyznacza obszar z punktu widzenia analiz przestrzennych. Skuteczniej unika się także przy jego stosowaniu problemów związanych z ulicami (ich układem opierającym się na liniach i skrzyżowaniach pod kątem prostym) i innymi naturalnymi barierami (co jest istotne zwłaszcza w przypadku łódzkiego, specyficznego układu ulic). Wybrany rozmiar heksagonu pozwala na dość dokładną wizualizację danych oraz zapewnia wystarczający poziom generalizacji wyników. Tym samym powstał obraz obszaru z wyszczególnieniem hierarchii przestrzeni. Jak wspomniano powyżej, w trzecim zastrzeżeniu do tej metody, taka generalizacja zyskuje na znaczeniu wraz ze wzrostem liczby analizowanych fotografii, a rangowanie obszarów staje się niezbędne przy większych zbiorach - przykładem może być praca Feick i Robertson (2014).

Wizualizacja za pomocą heksagonów niesie informację o najważniejszych obszarach i pozwala na wyznaczenie „rdzenia” zapamiętanego przez turystów miasta. Trudno jednak oczekiwać, aby respondenci, skupiając się na szczególnych obiektach, nie dostrzegali bliższego i dalszego otoczenia. W celu doprecyzowania obszaru najistotniejszego dla turystów w Łodzi, wokół każdego z punktów wytyczono pole o promieniu 250 m (rys. 3). Nawet po takim zabiegu zbiorczy obszar obejmujący całą przestrzeń w promieniu $250 \mathrm{~m}$ od punktu wykonania fotografii jest niewielki. Powierzchniowo zajmuje on $3,73 \mathrm{~km}^{2}$, co stanowi zaledwie 1,3\% obszaru całego miasta i $27 \%$ strefy wielkomiejskiej. Pokazuje to w wyraźny sposób, jak niewielki jest obszar najważniejszy dla turystów. Na całe miasto i sposób jego postrzegania rzutuje zatem obszar stanowiący zaledwie nieco ponad $1 \%$ jego powierzchni. Pomijając kwestie dojazdu do tego centralnie położonego terenu, większość miasta (różniąca się dość istotnie od śródmieścia) nie ma znaczenia. Miasto zostało zgeneralizowane i uproszczone do „esencji” - kluczowych fragmentów.

Kolejnym etapem badań było wzbogacenie mapy o największe atrakcje turystyczne miasta. Zabieg ten miał na celu porównanie obszaru wyznaczonego przez fotografie z lokalizacją obiektów potencjalnie budzących największe zainteresowanie wśród turystów. Wybór 15 „największych atrakcji Łodzi” został dokonany na podstawie strony internetowej Tripadvisor (2020) (największego na świecie turystycznego portalu z recenzjami obiektów noclegowych, gastronomicznych i atrakcji turystycznych). Decyzja o wyborze tego portalu motywowana była jego popularnością wśród turystów indywidualnych, samodzielnie planujących pobyt. Dodatkowo, jego zawartość w większości pokrywa się z treścią poradników i przewodników po mieście. Lista atrakcji jest również tożsama ${ }^{2} \mathrm{z}$ atrakcjami polecanymi przez władze miasta oraz organizacje turystyczne, w związku z czym można ją uznać za obiektywny wybór.

W wyniku połączenia efektów poszczególnych etapów procesu badawczego powstała syntetyczna mapa, skupiająca punkty wykonania wszystkich fotografii, heksagony o powierzchni 3 ha oznaczone barwami odpowiadającymi liczbie fotografii wykonanych na ich obszarze, ekwidystanty wyznaczające obszar o promieniu $250 \mathrm{~m}$ od punktu wykonania fotografii oraz lokalizację 15 „największych atrakcji turystycznych” według portalu Tripadvisor (rys. 3).

Grafika obrazuje silne powiązanie pomiędzy lokalizacją atrakcji a obszarem wyznaczonym na podstawie fotografii udostępnionych przez respondentów, które „najlepiej oddają wizerunek Łodzi”. Aż 13 z 15 największych atrakcji miasta leży w granicach lub bezpośrednim sąsiedztwie wyznaczonego obszaru. Wyjątkami są tylko: Stary Cmentarz (trójwyznaniowa nekropolia z okresu rozkwitu miasta, położona najdalej na wschód z wybranych punktów turystycznych) oraz Centralne Muzeum Włókiennictwa (punkt położony najdalej na południe). Przyczyna jest prosta - są to obiekty (podobnie jak Nowy Cmentarz Żydowski) oddalone od ścisłego centrum i deptakowej części ul. Piotrkowskiej. 


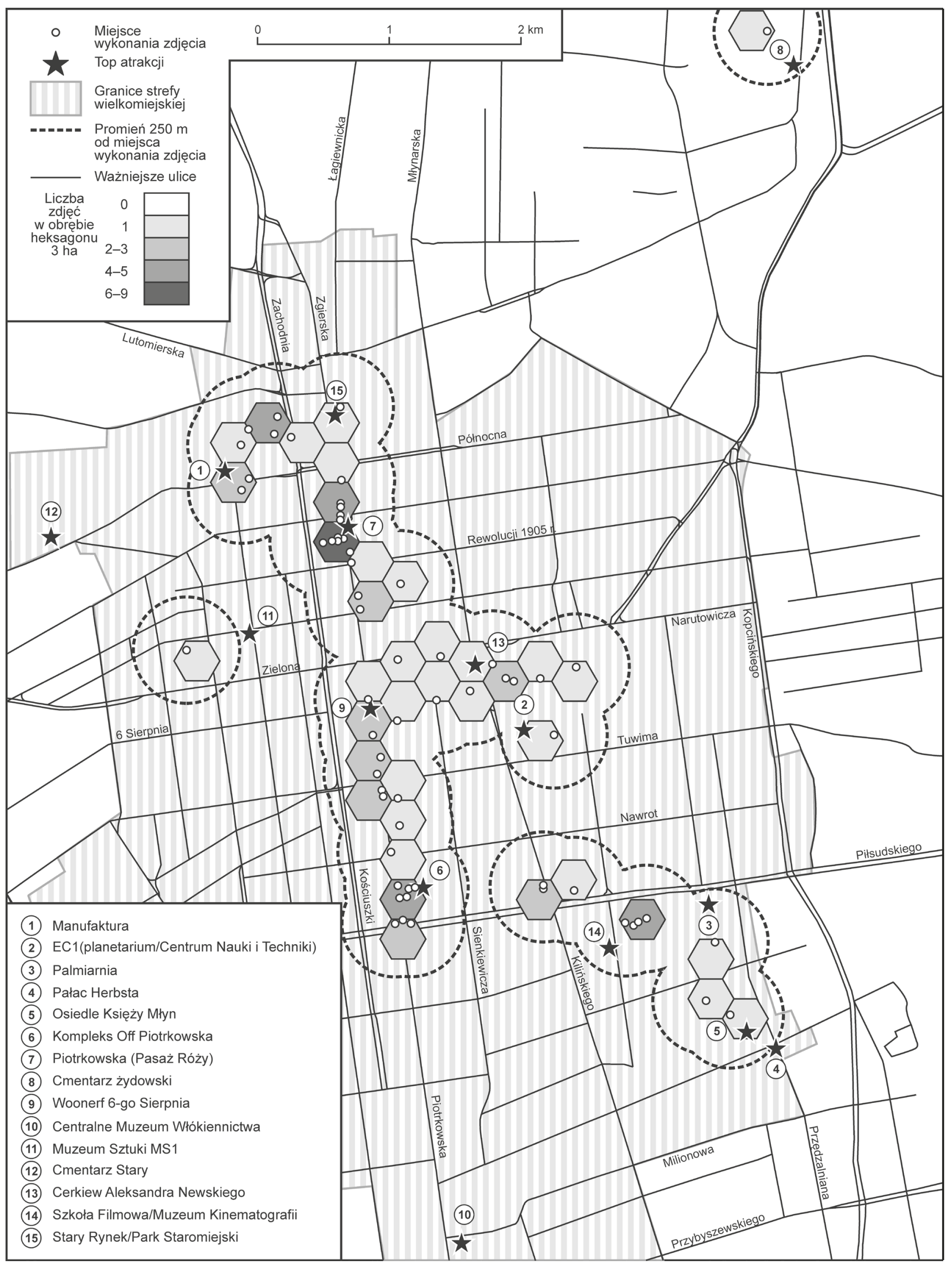

Rysunek 3. Mapa rozmieszczenia miejsc wykonania fotografii w przestrzeni Łodzi z uwzględnieniem największych atrakcji turystycznych miasta 
Zwiedzenie ich wymagałoby dojazdu lub dłuższego spaceru, przez co prawdopodobnie są one pomijane podczas krótszych (tak jak $\mathrm{w}$ przypadku tego badania) weekendowych pobytów.

Powyższe obserwacje dowodza, że bezpośrednie okolice największych atrakcji turystycznych, mieszczące się w stosunkowo niewielkiej odległości od siebie, mają największe znaczenie dla turystów krótko przebywających w Łodzi i są najchętniej przez nich odwiedzane. Do podobnych wniosków doszli Kadar i Gede (2013), używając zaawansowanego narzędzia do analiz tysięcy zdjęć zapisanych wraz z danymi geograficznymi - co pokazuje, że metoda geograficznej analizy fotografii bez użycia geodanych jest również skuteczna (choć bardziej czasochłonna i pewnie niemożliwa przy gigantycznych zbiorach danych).

\section{PODSUMOWANIE}

Analiza fotografii wykonanych przez turystów wydaje się cennym narzędziem uzupełniającym tradycyjne badania związane z turystyką i szerzej rozumianą przestrzenią turystyczną i jej wizerunkiem. Niniejsze badania były próbą sprawdzenia tej metody i mimo swych ograniczeń (niewielka liczba respondentów i fotografii) przyniosły interesujące wnioski, a w połączeniu z wiedzą pochodzącą z innych źródeł (w tym przypadku wywiadów pogłębionych) pozwoliły zdobyć nowe informacje.

Intencją autora było zaprezentowanie użycia takiej analizy $\mathrm{w}$ badaniach geograficznych i badaniach nad turystyką oraz nakreślenie jej zasad i możliwości - z pełną świadomością niecałkowitego wykorzystania jej potencjału, który wydaje się zależny od środków jakimi dysponuje badacz. Zaprezentowane $\mathrm{w}$ artykule sposoby interpretacji (strukturalistyczna, semiologiczna, hermeneutyczna i geograficzna) pokazały szerokie spektrum informacji, które można wydobyć z fotografii. Każde z podejść przynosi nieco inne wyniki, co sugerować powinno badaczom wybór drogi postępowania w zależności od poszukiwanych $\mathrm{w}$ danym badaniu informacji. Praktycznie każdy turysta wykonuje podczas podróży wiele fotografii - warto sięgnąć po dane w nich zapisane.

\section{PRZYPISY}

\footnotetext{
${ }^{1}$ Mem to zdjęcie, ilustracja lub krótki filmik, publikowany $\mathrm{w}$ Internecie, przedstawiający połączenie obrazu pewnej prawdziwej sytuacji lub postaci z mniej lub bardziej zabawnym komentarzem.

${ }^{2}$ Stan na czas badania. Ranking jest płynny, dlatego też kolejność atrakcji może ulegać zmianie.
}

\section{BIBLIOGRAFIA}

Barnard, M. (2001). Approaches to understanding visual culture. Houndmills: Palgrave. https://doi.org/10.1007/978-1-137-11046-6 Barthes, R. (1977). Image, music, text. London: Fontana.

Barthes, R. (1983). Selected writings. New York: Fontana.

Bauman, Z. (1978). Hermeneutics and social science. Approaches to understanding. London: Hutchison.

Becker, H. (1981). Exploring society photographically. Chicago: University of Chicago Press.

Bogunia-Borowska, M., Sztompka, P. (red.) (2012). Fotospołeczeństwo. Antologia tekstów z socjologii wizualnej. Kraków: Społeczny Instytut Wydawniczy Znak.

Bourdieu, P. (1990). Photography. A middle brow art. Cambridge: Polity Press.

Chlebuś-Grudzień, P. (2018). Selfie w muzeum - określenie paradygmatów analizy zjawiska fotografowania się na wystawach muzealnych. Turyzm, 28 (1), 7-13. https://doi. org/10.18778/0867-5856.28.1.01

De Choudhury, M., Feldman, M., Amer-Yahia, S., Golbandi, N., Lempel, R., Yu, C. (2010). Automatic construction of travel itineraries using social breadcrumbs. Pobrane z: http://research. microsoft.com/en-us/um/people/munmund/pubs/ht_10_long. pdf (23.10.2020). https://doi.org/10.1145/1810617.1810626

Duda, M. (2016). Sposób prezentacji oferty turystycznej na przykładzie katalogów wycieczek wybranych touroperatorów. W: J. Leśny, J. Nyćkowiak (red.), Badania i Rozwój Młodych Naukowców w Polsce. Gospodarka i ekonomia (s. 22-29). Poznań: Młodzi Naukowcy.

Edwards, E. (1997). Beyond the boundary. A consideration of the expressive in photography and anthropology. W: M. Banks, H. Morphy (red.), Rethinking visual anthropology. New Haven: Yale University Press.

Emmison, M., Smith, Ph. (2000). Researching the visual. London: Sage.

Feick, R., Robertson, C. (2014). A multi-scale approach to exploring urban places in geotagged photographs. Computers, environment and urban systems, 53, 96-109. https://doi.org/10.1016/j. compenvurbsys.2013.11.006

Fromm, E. (2003). Mieć czy być. Gdańsk: Dom Wydawniczy REBIS.

García-Palomares, J.C., Gutierrez, J., Mínguez, C. (2015). Identification of tourist hot spots based on social networks: A comparative analysis of European metropolises using photo-sharing services and GIS. Applied Geography, 63, 408-417. https://doi.org/10.1016/j.apgeog.2015.08.002

Goffman, E. (1979). Gender advertisements. London: Macmillan.

Gould, P., White, R. (1974). Mental maps. Progress in Human Geography, 19 (1), 105-110. https://doi.org/10.4324/9780203163757

Henny, L.M. (1986). Theory and practice of visual sociology. Current Sociology, 34 (3), 1-71. https://doi.org/10.1177/001139286034003003

$\mathrm{Hsu}, \mathrm{CH}$., Song, H. (2013). Destination image in travel magazines. A textual and pictorial analysis of Hong Kong and Macau. Journal of Vacation Marketing, 19 (3), 253-268. https:// doi.org/10.1177/1356766712473469

Hunter, W.C. (2012). Projected destination image: a visual analysis of Seoul. Tourism Geographies, 14 (3), 419-443. https://doi. org/10.1080/14616688.2011.613407

Jakiel, M., Bernatek, A. (2015). Postrzeganie wybranych typów krajobrazu przez różne grupy kulturowe na przykładzie mieszkańców Krakowa i Stambułu. Prace Komisji Krajobrazu Kulturowego, 29, 93-107.

Kadar, B., Gede, M. (2014). Where do tourists go? Visualizing and analysing the spatial distribution of geotagged photography. Cartographica. The International Journal for Geographic Information 
and Geovisualization, 48 (2), 78-88. https://doi.org/10.3138/ carto.48.2.1839

Konecki, K. (2005). Wizualne wyobrażenia. Główne strategie badawcze w socjologii wizualnej a metodologia pracy ugruntowanej. Przeglad Socjologii Jakościowej, 1 (1), 42-63.

Kotus, J., Rzeszewski, M. (2015). Zastosowanie „Metod mieszanych" do badania zachowań turystów w mieście - przykład konceptualizacji i wykorzystania (artykuł dyskusyjny). Turyzm, 25 (1), 57-67. https://doi.org/10.2478/tour-2014-0020

Kurashima, T., Iwata, T., Irie, G., Fujimura, K. (2013). Travel route recommendation using geotagged photos. Knowledge and information systems, 37 (1), 37-60. https://doi.org/10.1007/ s10115-012-0580-z

Leon, S. (2017). The semiotics of photography: Towards objective hermeneutics. Philosophy Study, 7 (12), 634-644. https://doi. org/10.17265/2159-5313/2017.12.002

Li, X. (2013). Multi-day and multi-stay travel planning using geo-tagged photos. W: D. Pfoser, A. Voisard (red.), Proceedings of the second ACM SIGSPATIAL international workshop on crowdsourced and volunteered geographic information (s. 1-8). New York: Association for Computing Machinery. https://doi. org/10.1145/2534732.2534733

Lynch, K. (1960). The Image of the city. Cambridge: MIT Press.

MacCannell, D. (2011). The ethics of sightseeing. London: University of California Press. https://doi.org/10.1525/9780520948655

Magala, S. (2000). Szkoła widzenia. Wrocław: Biblioteka Formatu.

Milman, A. (2011). The symbolic role of postcards in representing a destination image: the case of Alanya, Turkey. International Journal of Hospitality \& Tourism Administration, 12 (2), 144-173. https://doi.org/10.1080/15256480.2011.564495

Mirowska, N., Krysiak, S. (2015). Atrakcyjność wizualna krajobrazu doliny Mrogi i jej sąsiedztwa w gminie Dmosin. Acta Universitatis Lodziensis, Folia Geographica Physica, 14, 25-35. https://doi.org/10.18778/1427-9711.14.03

Mirzoeff, N. (1999). An introduction to visual culture. London: Routledge.

Peirce, Ch. (1955). Philosophical writings of Peirce. New York: Dover Publications.

Picazo, P., Moreno-Gil, S. (2019). Analysis of the projected image of tourism destinations on photographs: A literature review to prepare for the future. Journal of Vacation Marketing, 25 (1), 3-24. https://doi.org/10.1177/1356766717736350

Podhorecka, K. (2016). Ocena atrakcyjności wizualnej krajobrazu wybranych obszarów Polski. Turyzm, 26 (2), 33-38. https://doi. org/10.18778/0867-5856.26.2.04
Prosser, J., Schwartz, D. (1998). Photographs within the sociological research process. W: J. Prosser (red.), Image-based Research (s. 101-115). London: Routledge.

Puttilli, M. (2020). Everyday geographies in the changing city: subjective photo-routes in Mandalay, Myanmar. GeoJournal, 2020, 1-20. https://doi.org/10.1007/s10708-020-10263-8

de Saussure, F. (2002). Kurs językoznawstwa ogólnego. Warszawa: Wydawnictwo Naukowe PWN.

Shoval, N., Isaacson, M. (2010). Tourist mobility and advanced tracking technologies. London: Routledge. https://doi. org/10.4324/9780203869376

Smith, M. (2003). Issues in cultural tourism studies. London: Routledge. https://doi.org/10.4324/9780203402825

Sontag, S. (1978). On photography. New York: Farrar, Strauss and Giroux.

Stepchenkova, S., Zhan, F. (2013). Visual destination images of Peru: comparative content analysis of DMO and user-generated photography. Tourism Management, 36, 590-601. https:// doi.org/10.1016/j.tourman.2012.08.006

Strategia rozwoju Łodzi 2020+ (2013). Pobrane z: https://uml.lodz. pl/files/public/dla_mieszkanca/architektura_i_urbanistyka/publikacje/STRATEGIA_druk_24.07bez_markerow.pdf(23.10.2020).

Suchar, Ch. (1989). The sociological imagination and documentary still photography. The interrogatory stance. W: R.B. Flaes (red.), Eyes across the water. The Amsterdam conference on visual anthropology and sociology (s. 51-63). Amsterdam: Het Spinhuis. https://doi.org/10.1080/14725868908583637

Sztompka, P. (2005). Socjologia wizualna. Fotografia jako metoda badawcza. Warszawa: Wydawnictwo Naukowe PWN.

Tammet, T., Luberg, A., Jaarv, P. (2013). Sightsmap: crowd-sourced popularity of the world places. W: L. Cantoni, Z.P. Xiang (red.), Information and communication technologies in tourism 2013 (s. 314-325). Berlin-Heidelberg: Springer. https:// doi.org/10.1007/978-3-642-36309-2_27

Trasher, F.M. (1927). The gang. Chicago: Chicago University Press.

Tripadvisor (2020). Pobrane z: https://pl.tripadvisor.com/ Attractions-g274837-Activities-a_allAttractions.true-Lodz_ Lodz_Province_Central_Poland.html (23.10.2020).

Wieczorkiewicz, A. (2012). Apetyt turysty - o doświadczaniu świata w podróży. Kraków: Universitas.

Artykuł wpłynął: 25 października 2020

Zaakceptowano do druku: 30 listopada 2020 


\section{ZAŁĄCZNIK 1}

Dodatkowe informacje o autorach fotografii (badanych turystach)

\begin{tabular}{|l|l|}
\hline Nr respondenta & \multicolumn{1}{|c|}{ Cechy społeczno-demograficzne } \\
\hline 1 & mężczyzna, wiek średni, duże miasto, wykształcenie zawodowe, wcześniej jedynie przejeżdżał przez Łódź \\
\hline 7 & mężczyzna, wiek młodszy, duże miasto, wykształcenie wyższe, był w Łodzi kilka lat temu \\
\hline 10 & kobieta, wiek starszy, wieś, wykształcenie wyższe, nigdy wcześniej nie była w Łodzi \\
\hline 11 & mężczyzna, wiek starszy, duże miasto, wykształcenie zawodowe, nigdy wcześniej nie był w Łodzi \\
\hline 17 & mężczyzna, wiek średni, duże miasto, wykształcenie wyższe, nigdy wcześniej nie był w Łodzi \\
\hline 18 & kobieta, wiek średni, małe miasto, wykształcenie średnie, nigdy wcześniej nie była w Łodzi \\
\hline 19 & mężczyzna, wiek starszy, średnie miasto, wykształcenie wyższe, nigdy wcześniej nie był w Łodzi \\
\hline 20 & mężczyzna, wiek młodszy, wieś, wykształcenie wyższe, nigdy wcześniej nie był w Łodzi \\
\hline 23 & mężczyzna, wiek średni, duże miasto, wykształcenie średnie, nigdy wcześniej nie był w Łodzi \\
\hline
\end{tabular}

Źródło: opracowanie własne. 